\title{
Other Experiencer
}

National Cancer Institute

\section{Source}

National Cancer Institute. Other Experiencer. NCI Thesaurus. Code C92653.

A reference to someone other than the subject as being the one who has had an episode of the condition of interest, such as a disease. 